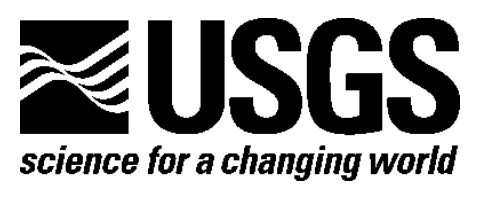

\title{
Dependence of Frictional Strength on Compositional Variations of Hayward Fault Rock Gouges
}

By Carolyn A. Morrow, Diane E. Moore, and David A. Lockner

Open-File Report 2010-1184

U.S. Department of the Interior

U.S. Geological Survey 


\section{U.S. Department of the Interior \\ KEN SALAZAR, Secretary}

\section{U.S. Geological Survey \\ Marcia K. McNutt, Director}

U.S. Geological Survey, Reston, Virginia 2010

For product and ordering information:

World Wide Web: http://www.usgs.gov/pubprod

Telephone: 1-888-ASK-USGS

For more information on the USGS-the Federal source for science about the Earth, its natural and living resources, natural hazards, and the environment:

World Wide Web: http://www.usgs.gov

Telephone: 1-888-ASK-USGS

\section{Suggested citation:}

Morrow, C.A., Moore, D.E., and Lockner, D.A., 2010, Dependence of frictional strength on compositional variations of Hayward fault rock gouges: U.S. Geological Survey Open-File Report 2010-1184, 19 p. [http://pubs.usgs.gov/of/2010/1184/].

Any use of trade, product, or firm names is for descriptive purposes only and does not imply endorsement by the U.S. Government.

Although this report is in the public domain, permission must be secured from the individual copyright owners to reproduce any copyrighted material contained within this report. 


\section{Contents}

Abstract... 15

\section{Figures}

1. A) Location of samples collected from surface outcrops along the Hayward Fault. B) Three-dimensional geologic map of Hayward Fault surfaces showing the various rock types brought into contact across the fault........................................ 2

2. Photomicrographs (crossed polarizers) of the six rock samples used in the experiments.

3. Coefficient of friction versus axial displacement for six Hayward Fault rocks.

4. Mixing laws of friction: a) Coefficient of friction at $9 \mathrm{~mm}$ displacement versus composition for three gouge mixtures not containing serpentinite. $b$ ) coefficient of friction versus composition for three gouge mixtures containing serpentinite.

5. Ternary diagram of serpentinite, gabbro, and graywacke friction.

6. Coefficient of friction versus phyllosilicate content for the quartz- and/or feldspar-rich rocks.

7. Frictional strengths of binary and ternary mixtures containing serpentinite, plotted with respect to their phyllosilicate contents.

\section{Tables}

1. Sample composition and strength parameters.

2. Coefficients for frictional strength mixing laws for Hayward rock types 


\title{
Dependence of Frictional Strength on Compositional Variations of Hayward Fault Rock Gouges
}

\author{
By Carolyn A. Morrow, Diane E. Moore, and David A. Lockner
}

\section{Abstract}

The northern termination of the locked portion of the Hayward Fault near Berkeley, California, is found to coincide with the transition from strong Franciscan metagraywacke to mélange on the western side of the fault. Both of these units are juxtaposed with various serpentinite, gabbro and graywacke units to the east, suggesting that the gouges formed within the Hayward Fault zone may vary widely due to the mixing of adjacent rock units and that the mechanical behavior of the fault would be best modeled by determining the frictional properties of mixtures of the principal rock types. To this end, room temperature, water-saturated, triaxial shearing tests were conducted on binary and ternary mixtures of fine-grained gouges prepared from serpentinite and gabbro from the Coast Range Ophiolite, a Great Valley Sequence graywacke, and three different Franciscan Complex metasedimentary rocks.

Friction coefficients ranged from 0.36 for the serpentinite to 0.84 for the gabbro, with four of the rock types having coefficients of friction ranging from $0.67-0.84$. The friction coefficients of the mixtures can be predicted reliably by a simple weighted average of the end-member dry-weight percentages and strengths for all samples except those containing serpentinite. For the serpentinite mixtures, a linear trend between endmember values slightly overestimates the coefficients of friction in the midcomposition ranges. The range in strength for these rock admixtures suggests that both theoretical and numerical modeling of the fault should attempt to account for variations in rock and gouge properties.

\section{Introduction}

A three-dimensional geologic model of the Hayward Fault in the San Francisco Bay Region shows that a number of different rock units are juxtaposed across the fault, both on the surface and at depth, in part as a result of lateral displacement (Graymer and others, 2005). The fault gouge formed therein is likely a mixture of these various rock types. In order to model the mechanical behavior of the fault, which is known both to creep and to produce large earthquakes, it is necessary to determine the frictional properties of mixtures of the principal rock types.

In this study, we focus on six rock units that appear in the three-dimensional geologic map. As noted by Graymer and others (2005), the active Hayward Fault zone forms part of the structural boundary between the Franciscan Complex on the west side and the Coast Range Ophiolite and Great Valley Sequence on the east side. Three Franciscan metasedimentary rock units were mapped on the west face of the fault at 
depth - Yolla Bolly terrane, Novato Quarry terrane, and Central terrane mélange — and all three were tested in this study. The three east-face rock types chosen for these experiments are the Joaquin Miller Formation of the Great Valley Sequence and serpentinite and gabbro of the Coast Range Ophiolite. Sample localities are shown in figure $1 A$.

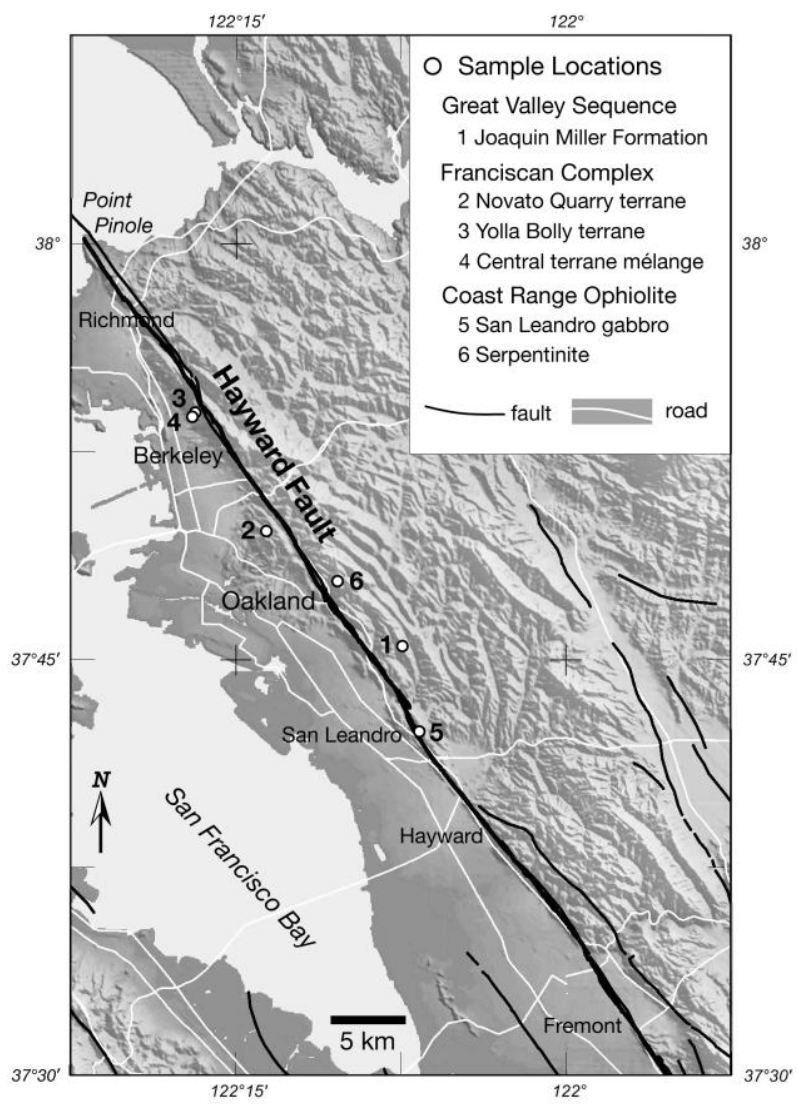

A)
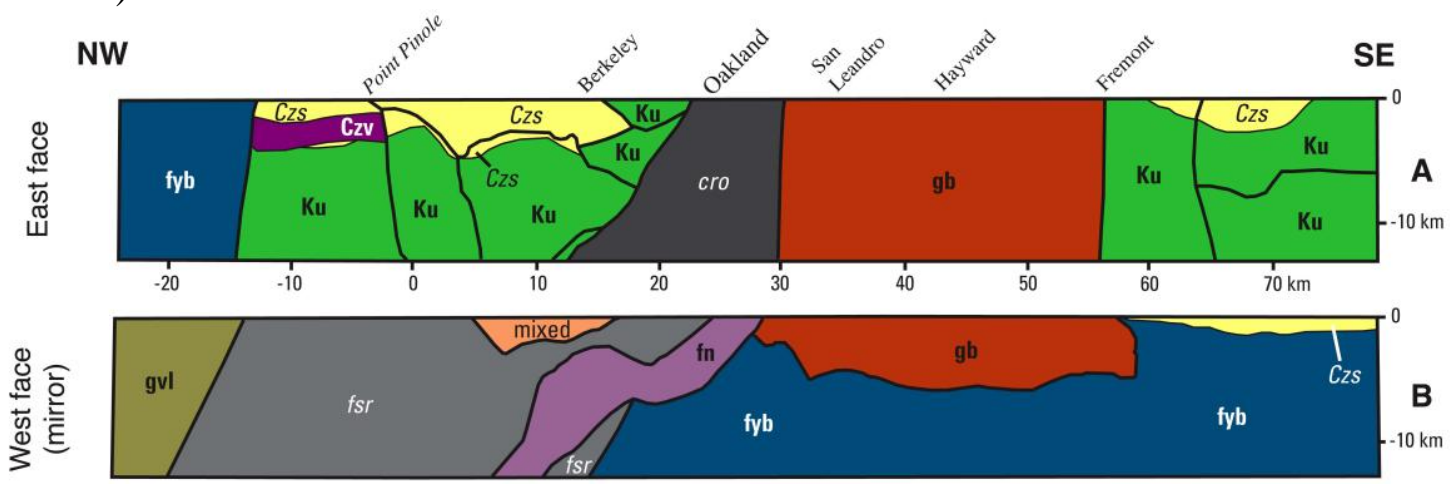

B)

Figure 1. A) Location of samples collected from surface outcrops along the Hayward Fault. $B$ ) Three-dimensional geologic map of Hayward Fault surfaces showing the various rock types brought into contact across the fault (after Graymer and others, 2005). 
We report the frictional strengths over a range of sliding rates of the six starting materials and of binary and ternary mixtures prepared from them. Although this work is directed towards the Hayward Fault, the Franciscan Complex, Great Valley Sequence, and Coast Range Ophiolite dominate the geology of the Coast Ranges of central and northern California. Results presented here, therefore, also are applicable to the San Andreas, Calaveras, Rodgers Creek, Maacama, and other faults of the San Andreas system in the Coast Ranges.

\section{Description of Hayward Fault Rocks}

Sample descriptions are based on optical and scanning electron microscope observations and bulk X-ray diffraction (XRD) analyses. Compositions of minerals in the gabbro and Great Valley Sequence graywacke, obtained by electron microprobe techniques, are reported by Moore and Ponce (2001). Additional information about the rock units and the regional structure of the San Francisco Bay area is provided by Blake and others (1984) and Graymer (2000). The numbering sequence corresponds to that in figure $1 A$. A two-dimensional geologic map of the two faces of the Hayward Fault, developed by Graymer and others (2005) (their figure $3 A, B$ ), is reproduced here (fig. $1 B$ ), and corresponding rock-unit symbols are included in the sample descriptions.

1. Great Valley Sequence, Late Cretaceous Joaquin Miller Formation ( $\mathrm{Ku})$. The sample is a calcite-cemented graywacke that is relatively rich in lithic fragments and feldspar clasts (fig. $2 A$ ). It contains $\sim 13$ modal percent phyllosilicate minerals, predominantly partly chloritized detrital biotite with minor amounts of detrital muscovite and secondary white mica (Moore and Ponce, 2001).

2. Franciscan Complex, Late Cretaceous Novato Quarry terrane (fn). This rock is a fine-grained, closely packed, arkosic metagraywacke (labeled "metasandstone" in the rest of the paper) (fig. $2 B$; note the difference in scale from fig. $2 A$ ). Detrital plagioclase has been completely altered to albite and minor pumpellyite and detrital K-feldspar has been altered to albite and phengitic white mica. In contrast to the calcite-cemented Great Valley Sequence graywacke, the matrix of this rock is rich in phyllosilicates. Overall, the rock contains $\sim 29$ modal \% phyllosilicates, the majority of them chlorite and partly chloritized biotite. There are a few traces of retrograde alteration consisting of adularia + montmorillonite + Fe-oxides.

3. Franciscan Complex, Late Jurassic-Early Cretaceous Yolla Bolly terrane (fyb). The Yolla Bolly rocks are among the oldest, highest-grade metasedimentary rocks of the Franciscan Complex. This metagraywacke contains the characteristic low-temperature blueschist-facies assemblage jadeite + glaucophane + lawsonite. It is a semischist, but the original clastic character is preserved locally, for example, the clusters of jadeite and glaucophane in figure $2 C$ have pseudomorphically replaced plagioclase and lithic grains, respectively. Some of the glaucophane is replaced partially by retrograde chlorite; this reaction may have accompanied late, brittle deformation of lawsonite and jadeite. The rock contains $\sim 30 \%$ phyllosilicates, in a roughly $2: 1$ ratio of phengite to chlorite. 

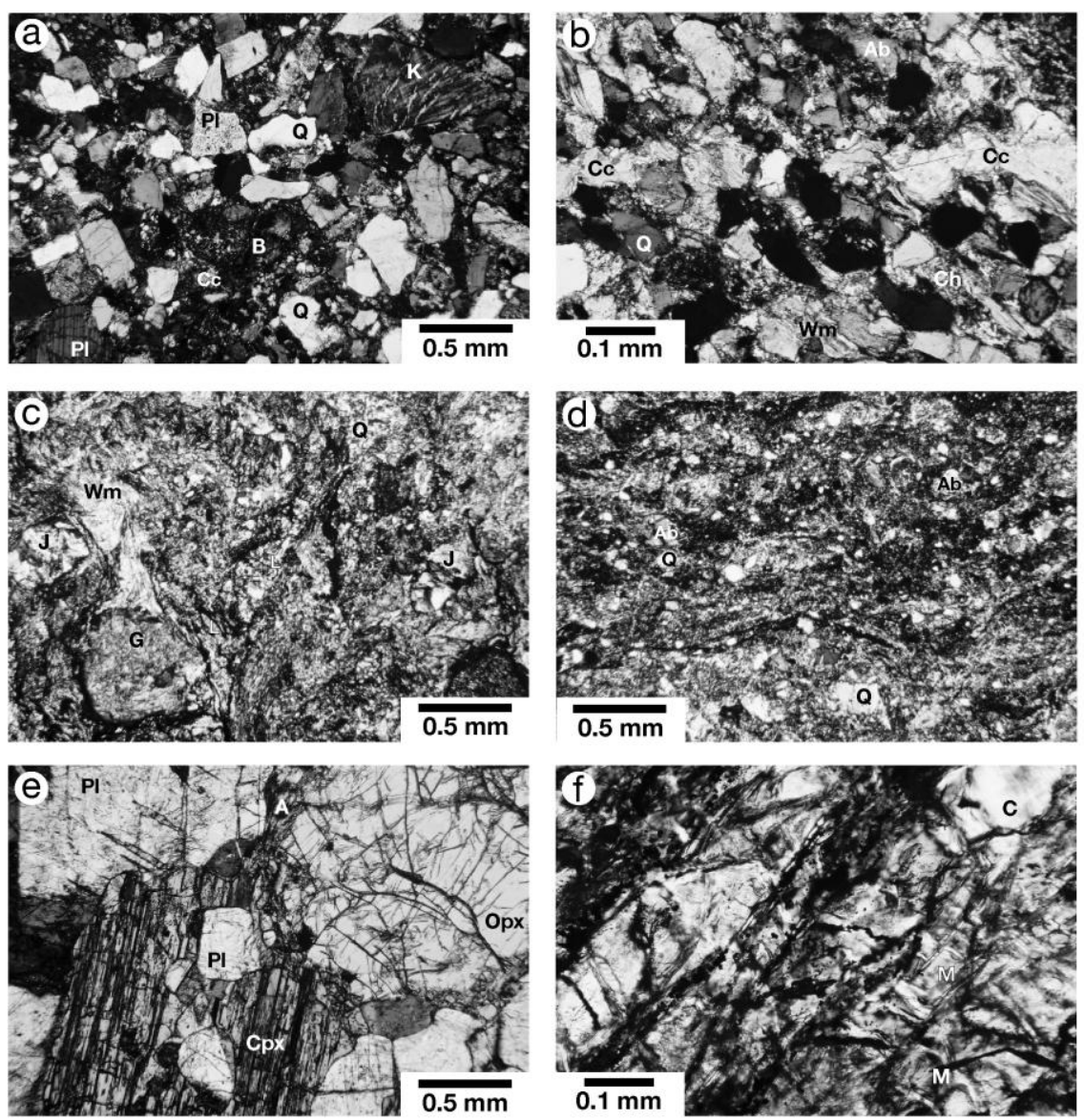

Figure 2. Photomicrographs (crossed polarizers) of the six rock samples used in the experiments. $A$ ), Great Valley Sequence (Joaquin Miller Formation) (Ku), an essentially unmetamorphosed, calcite (Cc)-cemented sandstone; K, K-feldspar; PI, plagioclase; B, biotite. B), Franciscan Complex (fn), Novato Quarry terrane, a fine-grained, pumpellyite-bearing metasedimentary rock. A discontinuous calcite vein crosses the photo from left to right; Ch: chlorite, Wm: white mica, Ab: albite. C), Franciscan Complex, Yolla Bolly terrane (fyb), jadeite (J) + glaucophane $(G)+$ lawsonite (L) metagraywacke; the marked clusters of jadeite and glaucophane pseudomorphically replace detrital grains. $D$ ), Franciscan Complex, Central terrane mélange (fsr). Although it is phyllosilicate-rich, the mélange also contains significant amounts of quartz and feldspar. E), Coast Range Ophiolite, San Leandro gabbro (gb); Opx, orthopyroxene; Cpx, clinopyroxene; A, amphibole. F), Coast Range Ophiolite (cro), serpentinite that is largely recrystallized but preserves some remnants of mesh $(\mathrm{M})$ and bastite texture. The serpentinite has also been sheared and brecciated; the chrysotile (C) at upper right may be a fragment of a brecciated vein.

4. Franciscan Complex, Central terrane mélange (fsr). The sampled outcrop of the mélange unit (fig. 1) consists of rock fragments of various lithologies and sizes immersed in a fine-grained matrix. The matrix material was collected for this study. It has a strong fabric resulting from penetrative shearing, and many of the larger clasts of quartz and feldspar in the mélange matrix are fractured (fig. 2D). Feldspars are thoroughly albitized, and quartz is partly recrystallized. Although pumpellyite was not identified in our sample, 
it has been reported in other mélange outcrops in the Bay area (Blake and others, 1984). Phyllosilicate minerals comprise roughly 50 modal \% of the sample and they consist largely of a mixture of chlorite and phengitic white mica. Younger calcite veins crosscut the foliation, and there is a minor overprint of the low-temperature retrograde assemblage adularia + montmorillonite +Ti-oxides + calcite + kaolinite.

5. Coast Range Ophiolite, Jurassic San Leandro gabbro (gb). The sample chosen for study is a coarse-grained gabbro whose igneous mineral assemblage is dominated by plagioclase, clinopyroxene, orthopyroxene and amphibole (fig. 2E). Low-temperature modifications include minor chloritization of the mafic minerals that is associated with narrow veinlets of Fe-oxides, and some zeolite-facies alteration (thomsonite + prehnite + albite). The total phyllosilicate content is $\sim 6$ modal \% (Moore and Ponce, 2001).

6. Coast Range Ophiolite, Jurassic serpentinite (cro). The serpentinite sample has been thoroughly sheared, and it consists of small pieces of bluish- to greenish-gray serpentinite in a fine-grained, pale-green matrix. A bulk sample was tested in this study. All three major serpentine minerals, antigorite, lizardite (6T polytype), and chrysotile, were identified in XRD patterns. Based on the relative heights of their (202) peaks, chrysotile and antigorite may be present in roughly equal amounts, with somewhat smaller amounts of lizardite. Some relics of mesh (fig. $2 F$ ) and bastite texture are preserved; overall, however, the original pseudomorphic textures have been obscured by recrystallization and deformation.

\section{Experimental Procedure}

Room-temperature triaxial sliding experiments (drained conditions) were performed in the laboratory on synthetic gouges prepared from the six Hayward Fault rocks. Each rock sample was crushed and sieved through a $100 \mu \mathrm{m}$ mesh screen and then dried in vacuum for twelve hours at 100 degrees centigrade. Pure and binary mixtures were created based on dry-weight percent of material at 10, 25, 50, 75, 90, and 100\% of end member constituents, as shown in Table 1. Ternary mixtures of gabbro, metagraywacke, and serpentinite were prepared by first making a 50-50 mixture of gabbro and graywacke and then combining it with 10, 25, 33, 50, 75 and $90 \%$ serpentinite. The prepared gouge was mixed with deionized water to form a paste, and then applied as a 1-mm thick layer between 30 degree sawcut sliding blocks composed of basalt. Basalt is strong enough to resist crushing regardless of the strength of the gouge layer. A hole was drilled through the top basalt block to allow for free flow of water into the gouge layer from the pore pressure system; a filter was used to prevent gouge material from extruding through the hole. The samples were then jacketed in polyurethane tubes and secured between steel end plugs with hose clamps. This sample configuration matches that used by Tembe and others, 2010, in their experiments on mixtures of quartz, montmorillonite, and illite.

Normal stress and pore-fluid pressure of 51 and $1 \mathrm{MPa}$, respectively, were applied to the sample for an effective normal stress of $50 \mathrm{MPa}$, simulating a depth of burial of around $3 \mathrm{~km}$. Normal stress was maintained by computer-controlled adjustments of confining pressure. A greased Teflon shim was placed between the piston and steel driving block to allow for lateral slip of the lower sample half as shearing occurred. For lower-strength samples, axial load was measured with an internal load cell. High-strength 
sample measurements relied on an external load cell. These measurements were adjusted for piston/seal friction. During the experiments, true contact area on the sliding surface was computed and shear and normal stresses were calculated in real time. Stresses, pressures, and displacements were recorded at one-second intervals. Shear stress was corrected for polyurethane jacket strength.

In each experiment, sliding began at a rate of $1.0 \mu \mathrm{m} / \mathrm{sec}$ for the first $3 \mathrm{~mm}$ of axial displacement and then alternated among 1.0, 0.1 and $0.01 \mu \mathrm{m} / \mathrm{sec}$ for a total of 9 $\mathrm{mm}$ to observe the effect of sliding rate on strength. The uncertainty in pressures and jacket strength give an accuracy of 0.01 for the coefficient of friction, $\mu$ (defined as shear stress/effective normal stress: $\left.\mu=\tau\left(\sigma_{n}-p\right)\right)$, and variability in sample preparation gives a repeatability of about 0.03 . Relative changes in strength within an individual experiment, used to determine velocity sensitivity, are significantly more accurate.

\section{Results}

\section{End-Member Samples}

Coefficients of friction, $\mu$, for the six Hayward Fault rocks are shown in figure 3. Following an initial rapid stress increase, all samples exhibited approximately constant strain hardening during the deformation tests. This strain hardening rate tended to correlate with sample strength (also reported by Tembe and others, 2010). Periodic strength transients in the deformation plots correspond to changes in the imposed sliding rate. Friction values at $9 \mathrm{~mm}$ axial displacement (10.4 $\mathrm{mm}$ slip on sawcut surface) ranged from 0.36 for the serpentinite to 0.84 for the gabbro. At room temperature and $100 \mathrm{MPa}$ effective normal stress, the frictional strengths of the individual serpentine minerals range from $\mu \approx 0.2$ for chrysotile to $\mu \approx 0.4-0.5$ for lizardite and antigorite (Moore and others, 1997; Morrow and others, 2000); values of $\mu$ at $50 \mathrm{MPa}$ will be slightly lower. The strength of the Hayward serpentinite sample is consistent with the mix of serpentine minerals that it contains. Values for the gabbro and graywacke $(\mu=0.75)$ are comparable to the post-failure frictional sliding strengths of intact samples of these same materials (Morrow and Lockner, 2001). Lockner and others (1982) reported a sliding friction value of $\mu=0.68$ for a pumpellyite-bearing Franciscan metagraywacke from the Geyser Peak area, which is essentially the same as the value for the comparable Novato Quarry metasandstone. 


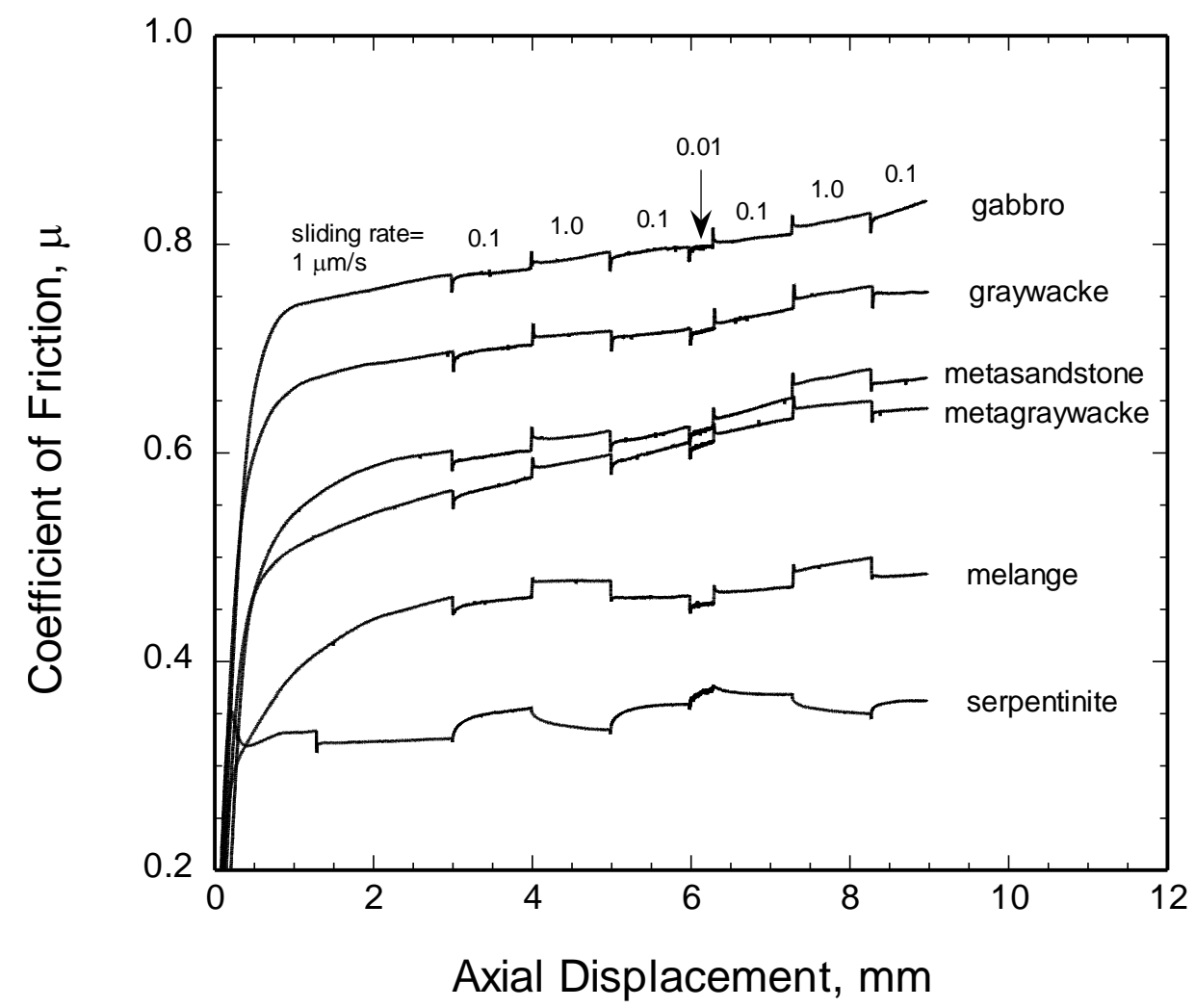

Figure 3. Coefficient of friction versus axial displacement for six Hayward Fault rocks. The sliding rate changed in decade steps throughout each experiment as indicated at the top of the figure. All samples were velocity strengthening except for serpentinite.

In Morrow and Lockner (2001), as well as in these current tests, sliding-rate changes during shearing caused discrete steps in the coefficients of friction. This velocity response can be characterized by the quantity $a-b$, where $a$ and $b$ represent the direct and evolutionary effects of a change in sliding velocity as:

$$
a-b=\mathrm{d} \mu_{s s} / \mathrm{d} \ln V,
$$

where $\mu_{s s}$ and $V$ denote the steady-state coefficient of friction and the slip velocity, respectively (Dieterich, 1979). All but the serpentinite sample exhibited velocity strengthening, that is, they were stronger at faster sliding rates. Positive values correlate with stable sliding (creep) (Rice and Ruina, 1983). The $a-b$ values for the velocitystrengthening gouges ranged from 0.0022 to 0.0062 (table 1 ). The frictional strengths equilibrated quickly in response to a velocity change, with values of $d_{c}$, the characteristic displacement of strength evolution, ranging from 0.087-0.164 $\mathrm{mm}$ (table 1). The serpentinite, on the other hand, exhibited velocity-weakening behavior (weaker at the faster sliding rates), with an $a-b$ value of -0.0113 . It should be noted, however, that serpentinites containing different proportions of the three serpentine minerals may be velocity strengthening over some velocity ranges (Moore and others, 1997). The $d_{c}$ value for this sample was around $0.817 \mathrm{~mm}$, indicating that a longer displacement was necessary to reach a new equilibrium friction level after a change in velocity compared to 
the velocity-strengthening samples. Note the broad exponential curve in the friction response of the serpentinite sample after each velocity change (fig. 3). The positive rate dependence observed in the gabbro and quartz-bearing samples probably is related to the continued strain-hardening, a process associated with nonlocalized shear, grain comminution, and densification. These are transient processes that, due to the limited total slip available in our experiments, appear to be operative for the full $9 \mathrm{~mm}$ of sliding. Therefore, it is likely that with continued sliding, strain hardening would cease and rate dependence would decrease. For this reason, the rate-dependence listed in table 1, while correct for the conditions tested, may not be generally applicable to the natural case where fault slip is greater than $9 \mathrm{~mm}$ and gouge particle-size distributions differ from our initial sample-size distributions. Further analysis of the velocity stepping data will be deferred until a future publication.

\section{Binary and Ternary Mixtures}

The strengths of binary mixtures of the Hayward Fault rocks at $9 \mathrm{~mm}$ of axial displacement (10.4 mm slip on sawcut) are illustrated in figure $4 A$ for the three gouge mixtures not containing serpentinite, and in figure $4 B$ for the binary and ternary mixtures containing serpentinite. Coefficients of friction decreased linearly with weight percent between the higher- and lower-strength end members in figure $4 A$. For the serpentinitemixture samples (fig. $4 B$ ), the relationship is more complicated. While the metagraywacke-serpentinite mixtures follow a linear mixing law, the samples that contain both gabbro and serpentinite are distinctly curved. In these plots, the serpentinite reduces frictional strength more than would be expected by its simple weight percent. The deviation from a linear response is greatest in the mid-weight percents with the discrepancy in $\mu$ being as much as 0.06 . The addition of only a small amount of serpentinite also has a significant effect on the steady state velocity dependence of the mixtures as well as the characteristic slip distance $d_{c}$ (see table 1). These observations suggest that the presence of serpentinite may have a significant effect on fault stability (that is, creeping versus locked or unstable behavior), as it does not take the addition of much serpentinite to change the rheological properties of the gouge mixtures. 


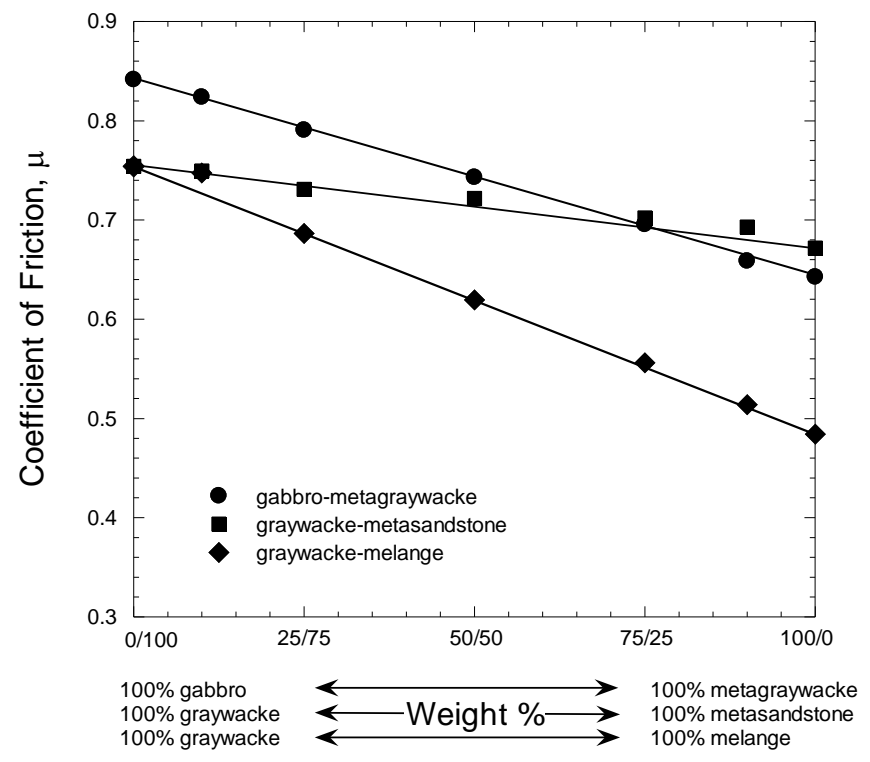

A)

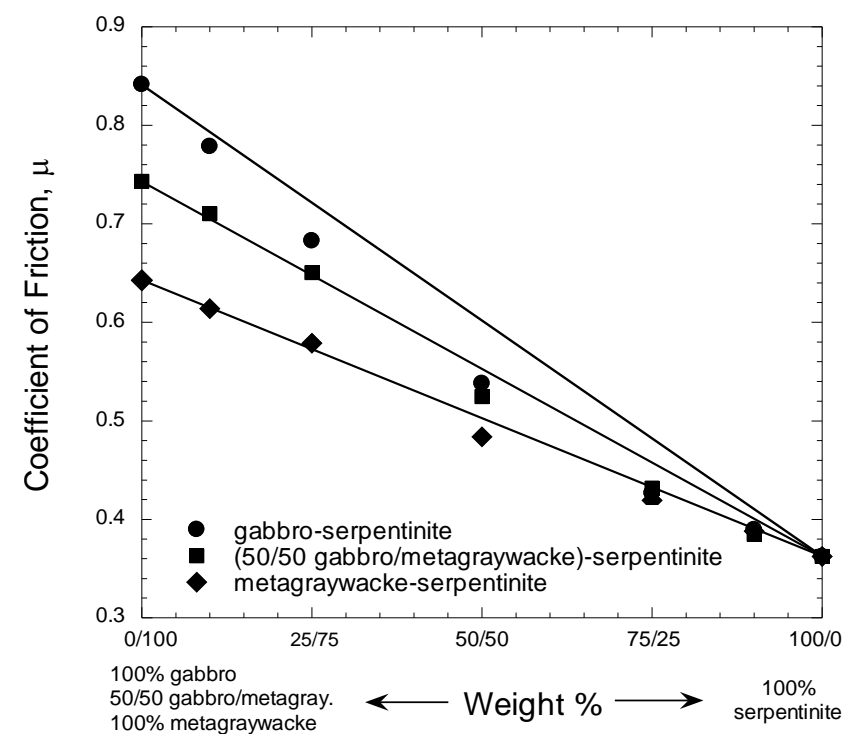

B)

Figure 4. Mixing laws of friction: a) Coefficient of friction at $9 \mathrm{~mm}$ displacement versus composition for three gouge mixtures not containing serpentinite. b) coefficient of friction versus composition for three gouge mixtures containing serpentinite. Straight lines connect end members and satisfy Equation (2) with coefficients in table 2.

Coefficients of friction of the serpentinite-gabbro-metagraywacke mixtures can be best illustrated in a ternary diagram (fig. 5), where the compositions of each sample are plotted as circles according to the weight percentages of the three end-member constituents. Circles along the three sides of the triangle represent binary mixtures of the end members as discussed above, and data in the interior represent the ternary mixtures. Contour lines of constant coefficient of friction were drawn based on the values at 9-mm axial displacement for each experiment. Coefficients of friction range from 0.36 to 0.84 
for the pure serpentinite and gabbro, respectively; ternary mixtures incorporating the intermediate-strength metagraywacke were themselves intermediate between the serpentinite and gabbro extremes.

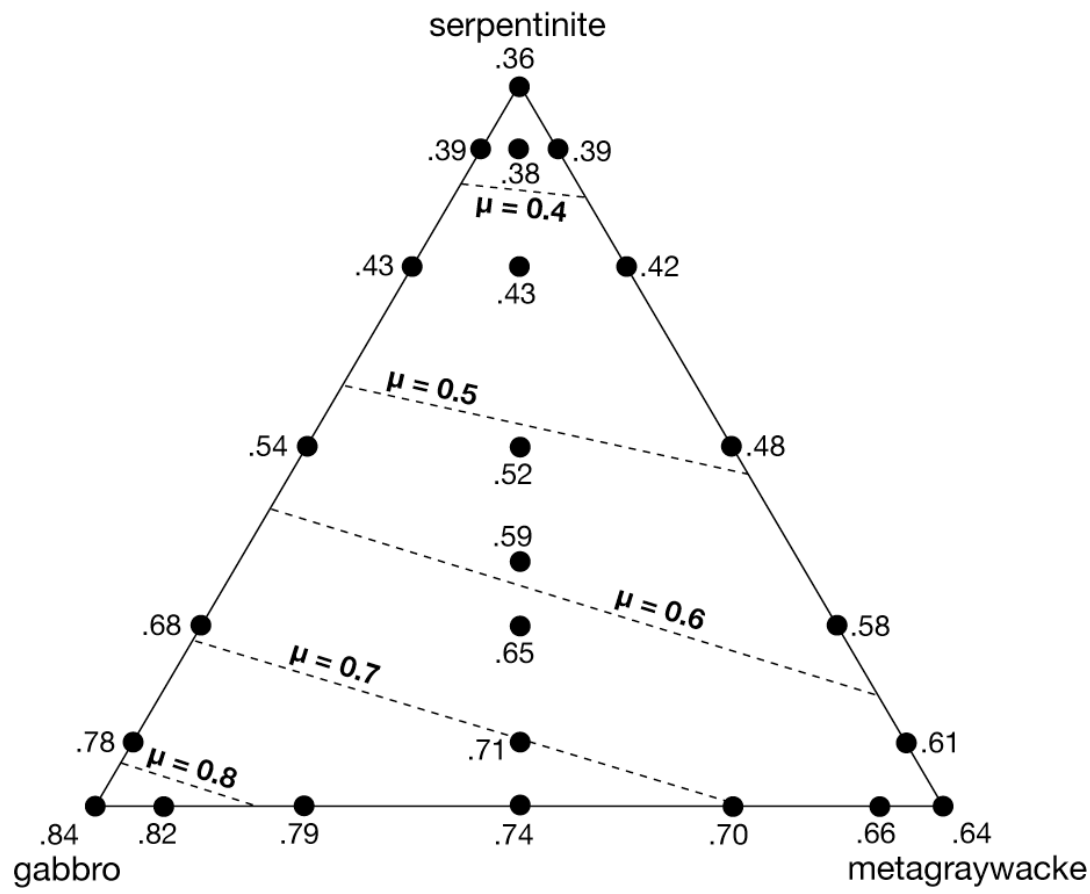

Figure 5. Ternary diagram of serpentinite, gabbro, and graywacke friction. Filled circles show gouge composition for each experiment. The numbers by the circles are the coefficients of friction, $\mu$, at $9 \mathrm{~mm}$ displacement, which were used to demark contour lines of $\mu$.

\section{Discussion}

The frictional strengths of the five quartz-and/or feldspar-rich starting materials are plotted in figure 6 relative to their total phyllosilicate contents. For consistency, the modal (volume) percentages obtained from the point counts, described previously, were converted to weight percentages. Because the densities of the sheet silicate minerals generally are intermediate between those of lower-density quartz and feldspar, and higher-density mafic and carbonate minerals, the modal and weight percentages are nearly identical. Over the compositional range of the tested samples, strength decreases linearly with increasing phyllosilicate content; a linear extrapolation of this trend to $100 \%$ phyllosilicates would yield $\mu \approx 0.1$ (fig. 6 ). However, such an extrapolation can lead to a significant underestimation of the weak end member. For example, consider the gabbroserpentinite system plotted as circles in figure $4 B$. When restricted to the measurements ranging from pure gabbro to 50/50 gabbro and serpentinite, the data conform to a linear mixing law that extrapolates to pure serpentinite friction of $\mu \sim 0.23$. The direct measure of pure serpentinite friction is significantly greater $(\mu=0.36)$.

The phyllosilicates in the five rock samples plotted in figure 6 are predominantly chlorite, phengite (a high-Si muscovitic mica), and detrital biotite and muscovite. Muscovite is the strongest of these phyllosilicate minerals and biotite the weakest (see 
fig. 10 of Moore and Lockner, 2004). Room-temperature, water-saturated strengths of biotite and muscovite at $50 \mathrm{MPa}$ effective normal stress were estimated from figure 8 of Moore and Lockner (2008), and the range of $\mu$ was added to figure 6 . All of the phyllosilicate minerals have substantially higher coefficients of friction than the value of $\mu$ derived from the extrapolated linear trend, indicating that the frictional strength mixing law must become nonlinear and flatten in the 50-100 percent phyllosilicate range (dashed line in figure 6). Indeed, all three mixtures shown in figure $4 A$ have less than 50 percent phyllosilicates and plot within the linear trending region in figure 6 . Viewed in this manner, the linear trends shown in figure $4 A$ are expected.

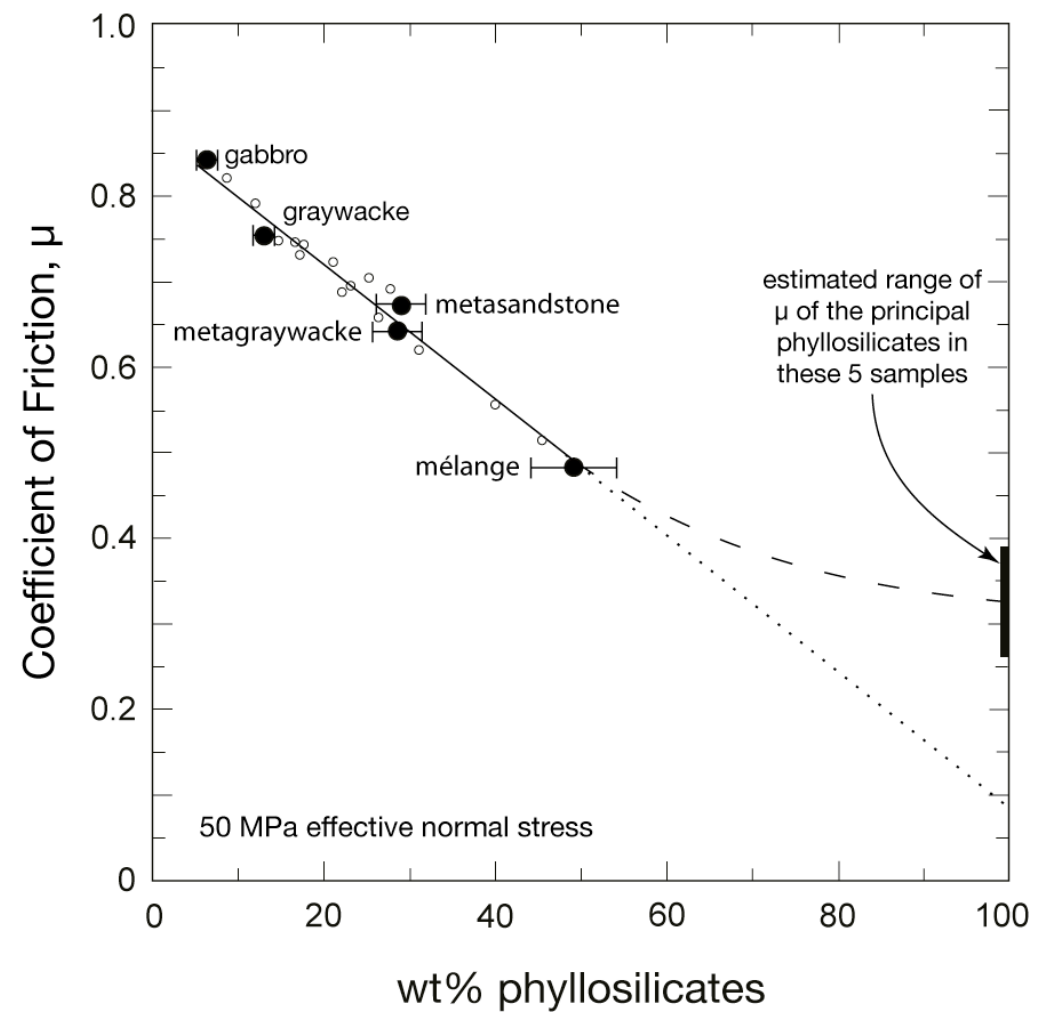

Figure 6. Coefficient of friction versus phyllosilicate content (weight percent) for the quartz- and/or feldspar-rich rocks. End-member samples are plotted as large, filled circles, and mixtures are plotted as small, open circles. Error bars are \pm 5 percent of the plotted phyllosilicate content. Strengths of these samples follow a linear trend that, extrapolated (dotted line), would yield $\mu \sim 0.1$ at 100 weight percent phyllosilicates, which is considerably lower than the strengths of the principal sheet silicates in the samples. The range of frictional values between 0 and 100 weight percent phyllosilicates must follow a nonlinear trend (dashed line, drawn here to a chlorite end member). 


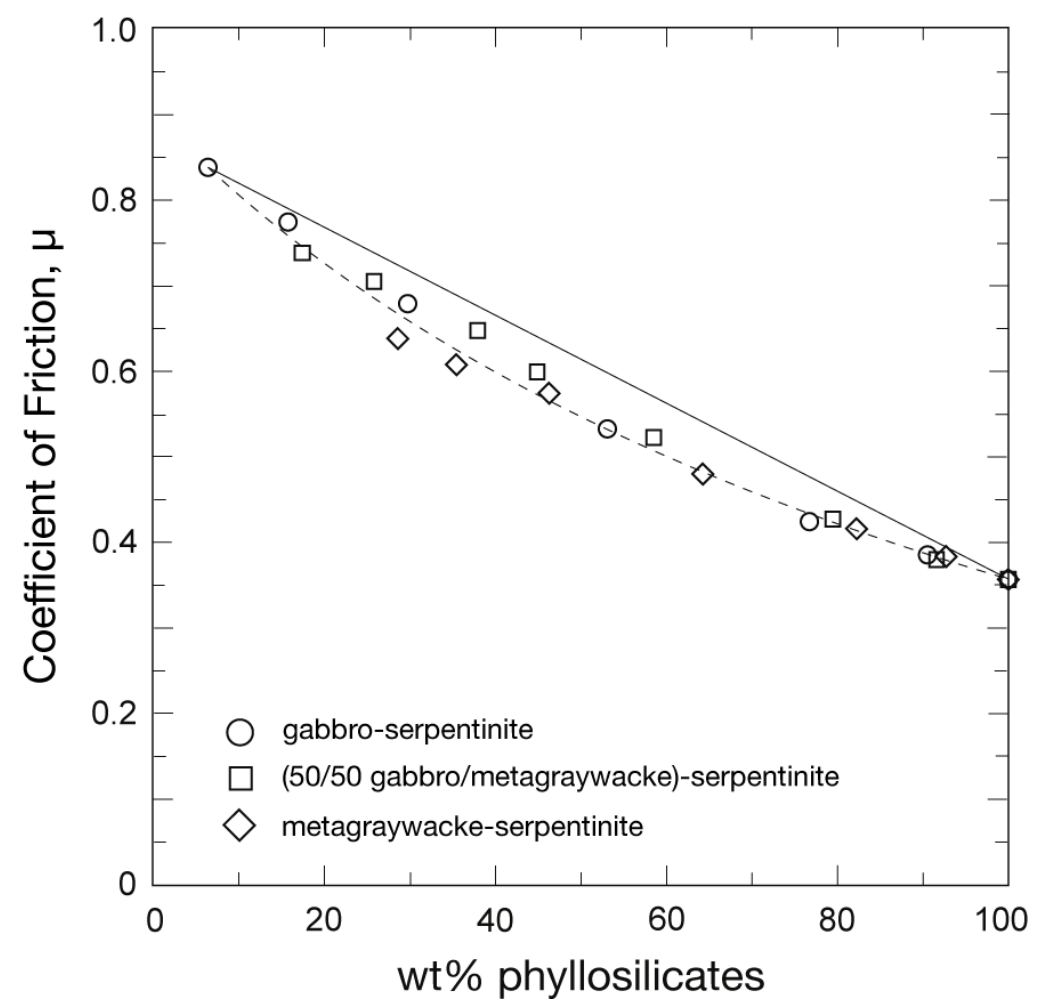

Figure 7. Frictional strengths of binary and ternary mixtures containing serpentinite, plotted with respect to their phyllosilicate contents. All of the data follow the slightly curved trend of the binary gabbro-serpentinite series.

The phyllosilicate contents of the gouge mixtures from figure $4 B$ were calculated using the values for gabbro and metagraywacke in figure 6 and assigning $~ 100$ percent phyllosilicate content for the serpentinite. Frictional strengths of those mixtures are replotted relative to their phyllosilicate contents in figure 7 . The slightly curved trend of the data essentially is the same as that for the gabbro-serpentinite series in figure $4 B$, and it is consistent with the overall curved trend in figure 6 . The sheet silicates in these mixtures thus have a greater impact on gouge strength than is indicated by their bulk concentration in the gouge. Mixtures of quartz with smectite clays (Lupini and others, 1982; Logan and Rauenzahn, 1987; Brown and others 2003; Takahashi and others, 2007; Tembe and others, 2010) or kaolinite (Crawford and others, 2008) also exhibit a non-linear frictional strength trend with varying clay content. It is commonly found that unusually weak minerals such as smectites tend to dominate shear strength of gouge mixtures when they are present in high concentrations (Lupini and others, 1982; Tembe and others, 2010) and lead to nonlinearity in the mixing laws at concentrations above about 60 percent. More detailed comparison of the results of this study with other mixing-law investigations will be made in a subsequent paper.

Nevertheless, for application to modeling studies of the Hayward Fault, the restricted range of phyllosilicate contents of most rock types, including the mélange matrix (fig. 6B), means that they can be related by linear mixing laws (fig. 6). Even for mixing between the strongest and weakest rock types tested, the gabbro and serpentinite, use of a linear mixing law would overestimate strength by, at most, 10 percent (figs. $4 \mathrm{~b}$, 
7). The more restricted compositional ranges of other mixtures involving serpentinite, such as the metagraywacke-serpentinite series, can be approximated by straight lines.

Therefore, from the largely linear trend of friction between end-member values, the coefficient of friction of a mixture, $\mu_{\text {mix }}$, can be expressed as a simple weighted average:

$$
\mu_{\text {mix }}=\mu_{1} x_{1}+\mu_{2} x_{2}+\mu_{3} x_{3}
$$

where $\mu_{\mathrm{i}}$ is the coefficient of friction of the $\mathrm{i}^{\text {th }}$ species and $\mathrm{x}_{\mathrm{i}}$ is the dry weight fraction of the $i^{\text {th }}$ species. For example, the coefficient of friction of a gabbro-mélange mixture would be:

$$
\mu_{\text {mix }}=(0.84)(\text { gabbro weight fraction })+(0.48)(\text { mélange weight fraction }) .
$$

Coefficients to be used in (2) are summarized in table 2.

Modeling of the frictional behavior of Hayward Fault gouge mixtures at nearsurface conditions is thus relatively straightforward, requiring only knowledge of the range of strength and compositional components of the end-member materials within the fault zone. There remains the important issue of how to determine the effects of diagenetic changes in the gouge as hydrothermal fluids circulate through the rocks. Such issues are best addressed by borehole studies in which fault structures can be directly observed, and by laboratory investigations conducted under hydrothermal conditions. For instance, fault rock analysis from the Nojima Fault in Japan (Ohtani and others, 2000) and the Great Sumatra Fault zone in Indonesia (Moore and others, 2001) give us direct observations of repeated behavior of vein filling in active fault zones. From this we can determine the extent of healing and sealing between rupture events. Studies of active faulting in Dixie Valley, Nevada (Barton and others, 1998) show how fluid circulation around fault zones is controlled by the orientation of in place stresses. In this case, unfavorably oriented faults tended to heal through vein-filling and precipitation reactions, while highly stressed faults would remain hydraulically conductive due to shearing. Recent laboratory tests indicate that the chemical contrast between ultramafic rocks, such as serpentinite, and quartzo-feldspathic rocks can affect the shear strength of mixtures of these rocks at hydrothermal conditions (Moore and others, 2008). These examples all illustrate how fault-zone materials at depth evolve with time, and how we might apply this insight to the Hayward Fault.

A primary goal of this study is to relate fault-zone rheology of the Hayward and other San Andreas system faults to deformation modes such as creeping versus locked regions, rupture nucleation sites, and distribution of microseismicity. The development of a three-dimensional geologic map allows us, for the first time, to address this issue in a meaningful way. Graymer and others (2005) compared subsurface geology to microseismicity patterns, geodetic slip inversions, surface creep rate, and rock strength. While they were not able to reach strong conclusions, their analysis should be considered a first step in relating fault composition to deformation style. Graymer and others (2005) considered rock strength as reported by Morrow and Lockner (2001) in their analysis. A comparison, for example, of peak intact strength from Morrow and Lockner (2001) with friction tests plotted in figure 4 shows a strong correlation between rock breaking 
strength and frictional strength. Still, frictional properties of gouge may better represent the shear resistance of well-developed faults, such as the Hayward.

With this in mind, one of the more striking deformation style features on the Hayward Fault is the apparent transition from locked to creeping zones in the 5 to $10 \mathrm{~km}$ depth range north of Berkeley (Graymer and others, 2005; Schmidt and others, 2005). This change in deformation style corresponds closely with the transition from mélange to metagraywacke on the western face of the fault. In this region, the eastern face consists of Great Valley Sequence graywacke. As shown in figure $4 A$, the mélange is a relatively weak gouge material and the contrast between mélange and metagraywacke frictional strength is nearly 0.2. Thus, the transition on the northern Hayward Fault from locked to creeping sections may well be the result of a transition on the west face of the fault from brittle, high frictional strength graywacke facies to more phyllosilicate-rich, weak mélange.

A second prominent feature is the deep locked portion of the fault centered between Oakland and San Leandro. This feature corresponds to the juxtaposition of Franciscan metagraywacke with Coast Range Ophiolite. Below $10 \mathrm{~km}$ (above 300 degrees centigrade) antigorite is expected to be the dominant serpentine phase, and the deeper material adjacent to the fault is likely to consist of ultramafic or mafic rock that has been partially serpentinized. The west side of the fault apparently consists of quartzose Franciscan rocks. Recent laboratory tests (Moore and Lockner, 2008; Moore and others, 2008) indicate that under these pressure/temperature conditions, silica will react with ultramafic minerals to form weak phases, such as talc, that promote creep. So the mineralogy would suggest creep at depth rather than a locked region as suggested by the geodetic data.

Farther south, between San Leandro and Fremont, gabbro is juxtaposed across the fault with gabbro and with metagraywacke. These are strong, brittle rocks and should remain so at mid-crustal depth. Relocated microseismicity in this region shows numerous clusters and repeating earthquakes (Waldhauser and Ellsworth, 2002), which would be expected from grinding of these rock types past each other. However, the modest but steady background creep, inferred to depths of $12 \mathrm{~km}$ from the geodetic modeling (Schmidt and others, 2005), would suggest the presence of distributed serpentine or other weak hydrous minerals.

Finally, the Hayward Fault south of Fremont places Franciscan metagraywacke against Great Valley sandstones and graywackes, as shown in Graymer and others, (1995). These are relatively strong rock types that should be locked and not susceptible to creep at depth. Yet this is the portion of the Hayward that shows the highest creep rate. Geophysical models based on gravity and magnetic anomalies (Ponce and others, 1995) suggest that the Coast Range Ophiolite (cro; figure $1 B$ ) may extend this far south, possibly explaining this apparent contradiction by the presence of distributed serpentine or other weak minerals within the fault zone at depth in the southern regions. Such details of fault geology at depth may be answered only by deep scientific drilling into the Hayward Fault.

The results presented here are from tests conducted at room temperature. Future work needs to focus on measuring frictional properties of Hayward Fault materials under hydrothermal conditions of elevated temperature and pressure. Given the many rock types that have been brought into contact by motion on the Hayward Fault, many 
processes involving dissolution/precipitation reactions are possible that can contribute to the complex behavior found on the Hayward and other San Andreas system faults.

\section{Conclusions}

A suite of room temperature/high pressure friction experiments was done on synthetic gouges prepared from six rock types found along the Hayward Fault. These surface samples are representative of rock types brought into contact at depth by lateral slip on the Hayward and other San Andreas system faults in northern California. Mixtures of different rock types were tested to determine the effect of composition on shear strength. Coefficients of friction, $\mu$, ranged from a low of 0.36 for the serpentinite to a maximum of 0.84 for the gabbro, correlating with phyllosilicate content. While the serpentinite and the Franciscan mélange were relatively weak, friction values for all other rock types were in the range of 0.67 to 0.84 . The friction coefficient of mixtures could be predicted reliably by a simple weighted average based on the dry-weight percentage of the constituents. The northern termination of the locked portion of the Hayward Fault near Berkeley is found to coincide with the transition from strong Franciscan metagraywacke to mélange on the western side of the fault. Laboratory tests on these gouge materials showed a significant reduction in frictional strength, as well as a tendency for stable creep due to the large percentage of phyllosilicates in the mélange. In the central and southern Hayward, gabbro, sandstone and metagraywackes are found in contact across the fault. These strong, brittle rock types are likely to be responsible for the zones of microseismicity and repeating earthquakes that are observed. However, repeating microearthquakes and the regions of deep aseismic creep would seem to require the presence of extensive regions of diffuse serpentinite or other weak mineral phases in the fault zone. It is likely that confirmation of this model will not occur until deep drilling of the Hayward Fault is undertaken.

\section{Acknowledgments}

We thank Russ Graymer for furnishing four of the rock samples used in this study and for suggesting sampling localities for the other two. David Ponce provided the map base used to plot sample localities in figure 1. Nick Beeler and David Ponce gave helpful reviews. Funding was provided by the NEHRP Program.

\section{References cited}

Barton, C., Hickman, S., Morin, R., Zoback, M.D., and Benoit, R., 1998, Reservoir-scale fracture permeability in the Dixie Valley, Nevada, geothermal field, in Holt, R.M. and others, eds., Rock Mechanics in Petroleum Engineering, v. 2, Society of Petroleum Engineers, Richardson, TX, p. 315-322.

Blake, M.C., Jr., Howell, D.G., and Jayko, A.S., 1984, Tectonostratigraphic terranes of the San Francisco Bay Region, in Blake, M.C., Jr., ed., Franciscan Geology of Northern California, Pacific Section SEPM, v. 43, p. 5-22. 
Brown, K.M., Kopf, A., Underwood, M.B., and Weinberger, J.L., 2003, Compositional and fluid pressure controls on the state of stress on the Nankai subduction thrust in a weak plate boundary, Earth \& Planetary Science Letters, v. 214, p. 589-603, doi:10.1016/S0012-821X(03)00388-1.

Crawford, B.R., Faulkner, D.R., and Rutter, E.H., 2008, Strength, porosity and permeability development during hydrostatic and shear loading of synthetic quartz-clay fault gouge, Journal of Geophysical Research, v. 113, B0307, doi $10.1029 / 2006 \mathrm{JB} 004634$.

Dieterich, J.H., 1979, Modeling of rock friction: 1. Experimental results and constitutive equations, Journal of Geophysical Research, v. 84, 2,161-2,168.

Graymer, R.W., 2000, Geologic map and database of the Oakland metropolitan area, Alameda, Contra Costa, and San Francisco Counties, California, U.S. Geological Survey Miscellaneous Field Studies Map MF-2342.

Graymer, R.W., Ponce, D.A., Jachens, R.J., Simpson, R.W., Phelps, G.A., and Wentworth, C.W., 2005, Three-dimensional geologic map of the Hayward Fault, northern California: Correlation of rock units with variations in seismicity, creep rate, and fault dip, Geology, v. 33, no. 6, p. 521-524.

Lockner, D.A., Summers, R., Moore, D., and Byerlee, J.D., 1982, Laboratory measurements of reservoir rock from the Geysers geothermal field, California, International Journal of Rock Mechanics \& Mineral Science, v. 19, p. 65-80.

Logan, J.M., and Rauenzahn, K.A., 1987, Frictional dependence of gouge mixtures of quartz and montmorillonite on velocity, composition and fabric, Tectonophysics, v. 144, p. $87-108$.

Lupini, J.F., Skinner, A.E., and Vaughn, P.R., 1981, The drained residual strength of cohesive soils, Géotechnique, v. 31, p. 181-213.

Moore, D.E., Hickman, S., Lockner, D.A., and Dobson, P.F., 2001, Hydrothermal minerals and microstructures in the Silangkitang geothermal field along the Great Sumatra Fault zone, Sumatra, Indonesia, Geological Society of America Bulletin, v. 113, no. 9, p. 1179-1192.

Moore, D.E., and Lockner, D.A., 2004, Crystallographic controls on the frictional behavior of dry and water-saturated sheet structure minerals, Journal of Geophysical Research, v. 109, B03401, doi 10.1029/2003JB002582.

Moore, D.E., Lockner, D.A., Ma, S., Summers, R., and Byerlee, J.D., 1997, Strengths of serpentinite gouges at elevated temperatures, Journal of Geophysical Research, v. 102, no. B7, p.14787-14801.

Moore, D.E., and Lockner, D.A., 2007, Friction of the smectite clay montmorillonite: a review and interpretation of data, in Dixon, T.H. and Moore, J.C., (eds.), The Seismogenic Zone of Subduction Thrust Faults, MARGINS Theoretical and Experimental Earth Science Series, v. 2, p. 317-345.

Moore, D.E., and Lockner, D.A., 2008, Slow-speed weakening of serpentinite sheared against quartzo-feldspathic rocks: Implications for fault creep in the San Andreas system, Eos, Transactions AGU, v. 89, no. 53, Fall Meeting Supplement, Abstract S41A-1829. 
Moore, D.E., Lockner, D.A., and Ponce, D.A., 2008, Weakening of serpentinite sheared against quartzo-feldspathic rocks and its possible implications for creep on the Hayward and Calaveras Faults, Third Conference on Earthquake Hazards in the Eastern San Francisco Bay Area, California State University East Bay, Oct. 2224, 2008 (abstract).

Moore, D.E., and Ponce, D.A., 2001, Petrography and physical properties of selected rock types associated with the Hayward Fault, U.S. Geological Survey Open File Report 01-263

Morrow, C.A., Moore, D.E., and Lockner, D.A., 2000, The effect of mineral bond strength and adsorbed water on fault gouge frictional strength, Geophysical Research Letters, v. 27, p. 815-818.

Morrow, C.A., and Lockner, D.A., 2001, Hayward Fault rocks: Porosity, density and strength measurements, U.S. Geological Survey Open File Report 01-421.

Ohtani, T., Fujimoto, K., Ito, H., Tanaka, H., Tomida, N., and Higuchi, T., 2000, Fault rocks and past to recent fluid characteristics from the borehole survey of the Nojima Fault ruptured in the 1995 Kobe earthquake, southwest Japan, Journal of Geophysical Research, v. 105, no. B7, p. 16,161-16,171.

Ponce, D.A., Graymer, R.W., Jachens, R.C., Williams, R.A., Simpson, R.W., Wentworth, C.M., and Roberts, C.W., 2005, Southern extension of the Hayward Fault and its relationship to the Calaveras and Silver Creek Faults, northern California (abs): Geological Society of America, Abstracts with Programs, v. 37, no. 4, p. 90.

Rice, J.R., and Ruina, A.L., 1983, Stability of steady frictional slipping, Journal of Applied Mechanics, v. 50, p. 343-349.

Schmidt, D.A., Burgmann, R., Nadeau, R.M., and d'Alessio, M., 2005, Distribution of aseismic slip rate on the Hayward Fault inferred from seismic and geodetic data, Journal of Geophysical Research, v. 110, B08406, doi 10.1029/2004JB003397.

Takahashi, M., Mizoguchi, K., Kitamura, K., and Masuda, K., 2007, Effects of clay content on the frictional strength and fluid transport property of faults, Journal of Geophysical Research, v. 112, B08206, doi:10.1029/2006JB004678.

Tembe, S., Lockner, D., and Wong, T.-f., 2010, Effect of clay content and mineralogy on frictional sliding behavior of simulated gouges: Binary and ternary mixtures of quartz, illite, and montmorillonite, Journal of Geophysical Research, v. 115, B03416, doi 10.1029/2009JB006383.

Waldhauser, F. and Ellsworth, W.L., 2002, Fault structure and mechanics of the Hayward Fault, California, from double-difference earthquake locations, Journal of Geophysical Research, v. 107B, p.1-15 
Table 1. Sample composition and strength parameters.

\begin{tabular}{|c|c|c|c|}
\hline Sample Weight $\%{ }^{1}$ & $\mu$ at $9 \mathrm{~mm}^{2}$ & $a-b^{3}$ & $\mathrm{~d}_{\mathrm{c}} \mathrm{mm} \mathrm{m}^{4}$ \\
\hline \multicolumn{4}{|l|}{ Single and binary: } \\
\hline GWK100 & 0.754 & 0.0026 & 0.102 \\
\hline GWK90 + MSS10 & 0.749 & 0.0033 & 0.096 \\
\hline GWK75 + MSS25 & 0.731 & 0.0032 & 0.121 \\
\hline GWK50 + MSS50 & 0.722 & 0.0036 & 0.073 \\
\hline GWK25 + MSS75 & 0.702 & 0.0038 & 0.090 \\
\hline GWK10 + MSS90 & 0.693 & 0.0038 & 0.083 \\
\hline MSS100 & 0.672 & 0.0040 & 0.087 \\
\hline GWK90 + MEL10 & 0.747 & 0.0027 & 0.096 \\
\hline GWK75 + MEL25 & 0.687 & 0.0038 & 0.112 \\
\hline GWK50 + MEL50 & 0.619 & 0.0045 & 0.129 \\
\hline GWK25 + MEL75 & 0.556 & 0.0055 & 0.126 \\
\hline GWK10 + MEL90 & 0.514 & 0.0059 & 0.144 \\
\hline MEL100 & 0.484 & 0.0062 & 0.162 \\
\hline GAB100 & 0.842 & 0.0022 & 0.155 \\
\hline GAB90 + SER10 & 0.779 & -0.0013 & 0.300 \\
\hline GAB75 + SER25 & 0.683 & -0.0052 & 0.406 \\
\hline GAB50 + SER50 & 0.538 & -0.0095 & 0.637 \\
\hline GAB25 + SER75 & 0.427 & -0.0124 & 0.678 \\
\hline GAB10 + SER90 & 0.390 & -0.0119 & 0.725 \\
\hline SER100 & 0.362 & -0.0113 & 0.817 \\
\hline GAB90 + MGW10 & 0.824 & 0.0025 & 0.114 \\
\hline GAB75 + MGW25 & 0.791 & 0.0022 & 0.153 \\
\hline GAB50 + MGW50 & 0.743 & 0.0030 & 0.132 \\
\hline GAB25 + MGW75 & 0.696 & 0.0036 & 0.114 \\
\hline GAB10 + MGW90 & 0.659 & 0.0027 & 0.149 \\
\hline MGW100 & 0.643 & 0.0035 & 0.164 \\
\hline MGW90 + SER10 & 0.614 & 0.0036 & 0.193 \\
\hline MGW75 + SER25 & 0.579 & 0.0029 & 0.248 \\
\hline MGW50 + SER50 & 0.484 & -0.0048 & 0.353 \\
\hline MGW25 + SER75 & 0.419 & -0.0095 & 0.620 \\
\hline MGW10 + SER90 & 0.388 & -0.0095 & 0.783 \\
\hline \multicolumn{4}{|l|}{ Ternary: } \\
\hline GAB45 + MGW45 + SER10 & 0.710 & 0.0029 & 0.180 \\
\hline GAB37.5 + MGW37.5 + SER25 & 0.650 & 0.0010 & 0.308 \\
\hline GAB33.3 + MGW33.3 + SER33.3 & 0.593 & -0.0042 & 0.379 \\
\hline GAB25 + MGW25 + SER50 & 0.525 & -0.0074 & 0.607 \\
\hline GAB12.5 + MGW12.5 + SER75 & 0.432 & -0.0115 & 0.648 \\
\hline GAB5 + MGW5 + SER90 & 0.385 & -0.0106 & 0.829 \\
\hline
\end{tabular}

${ }^{\mathrm{I}}$ Weight percent of constituents: graywacke (GWK), metasandstone (MSS), mélange (MEL), gabbro $(\mathrm{GAB})$, metagraywacke (MGW), and serpentinite (SER).

${ }^{2} 9 \mathrm{~mm}$ axial shortening corresponds to $10.4 \mathrm{~mm}$ displacement on the 30 degree inclined sawcut surfaces and a nominal strain of 10.4. Typical uncertainty in $\mu$ is \pm 0.01 ( 2 standard deviations).

${ }^{3}$ Based on the average of several relative changes in $\mu$ within each experiment. Estimated uncertainty \pm 0.001 for samples that contain 25 percent or less serpentinite and \pm 0.003 for greater than $25 \%$ serpentinite.

${ }^{4}$ Characteristic displacement, $d_{c}$, based on the average $d_{c}$ of several sliding rate changes within each experiment. Estimated uncertainty $\pm 0.066 \mathrm{~mm}$ for samples that contain 25 percent or less serpentinite and $\pm 0.095 \mathrm{~mm}$ for samples that contain greater than 25 percent serpentinite. 
Table 2. Coefficients for frictional strength mixing laws for Hayward rock types ${ }^{1,2}$.

\begin{tabular}{|l|l|l|l|l|l|l|}
\hline Mixture & GWK & MSS & MEL & GAB & SER & MGW \\
\hline graywacke + metasandstone & 0.754 & 0.672 & 0.484 & & & \\
\hline graywacke + mélange & 0.754 & & & & & \\
\hline gabbro + serpentinite & & & & 0.842 & 0.362 & \\
\hline gabbro + metagraywacke & & & & 0.842 & & 0.643 \\
\hline metagraywacke + serpentinite & & & & & 0.362 & 0.643 \\
\hline $\begin{array}{l}\text { gabbro + metagraywacke + } \\
\text { serpentinite }\end{array}$ & & & & 0.842 & 0.362 & 0.643 \\
\hline
\end{tabular}

${ }^{\mathrm{I}}$ Rock abbreviations from Table 1.

${ }^{2}$ Coefficients $\left(\mu_{\mathrm{i}}\right)$ from Equation (2): $\mu=\mathrm{S} \mu_{\mathrm{i}} \mathrm{x}_{\mathrm{i}}$. 